\title{
2
}

\section{Geographical Uneven Development and Regional Futures: A Conversation}

\author{
Ray Hudson and John Pickles
}

As part of the RegPol ${ }^{2}$ Project "Socio-economic and Political Responses to Regional Polarization in Central and Eastern Europe" Ray and John were invited to hold a wide-ranging conversation about critical economic geography and regional development. The context for the conversation was an on-going research programme involving scholars based in Leipzig and their colleagues interested in the intense processes of regional change in Central and Eastern Europe. The wider project- "Coping with uneven development: socio-economic and political responses to regional polarisation"-focused on two key issues: First, post-1989 political and economic transformation and the emergence of spatially complex forms of representative democracy and economic forms of private instead of state-led markets. Second, the more recent emergence of new forms of social and regional polarisation and

\author{
R. Hudson ( $\square)$ \\ Durham University, Durham, UK \\ J. Pickles \\ University of North Carolina, Chapel Hill, NC, USA \\ (C) The Author(s) 2019 \\ T. Lang and F. Görmar (eds.), Regional and Local Development


the corresponding political renewal of authoritarian state power in several Visegrad countries. We hope this conversation on the theme of contemporary critical economic geography contributes to the broader discussions about post-socialist regional futures.

John: Democratisation, liberalisation and privatisation after 1989 resulted in massive changes in post-socialist Europe. For some, opportunities increased as individuals entered real estate, commercial, and service sector occupations, particularly as state institutions and enterprises were hollowed-out and new management installed. For others, job loss and industrial decline led to regional involution and rapid deepening of social and regional inequalities. Across Central and Eastern Europe the record of the past two decades has thus been highly uneven across national economies and within and between regions. In the past few years, the political consequences of these regional economic transformations, the globalisation and integration of post-socialist economies, and the deepening of fiscal and legitimation crises in the EU and Eurozone have become ever sharper. Regional inequalities, unemployment and precarious futures have deepened experiences of economic marginalisation and social alienation, as shifting patterns of population have deepened xenophobia and petty nationalisms and support for authoritarian populist parties.

In these circumstances, it is no surprise that economic geographers in Central and Eastern Europe have increasingly turned their attention to questions of regional development, economic change, innovation and involution, socio-spatial inequality, and spatial justice. Some have developed and promoted new journals in regional science and regional economics to address questions of efficient resource allocation (see the Hungarian Regional Statistics). Some have focused on institutional and ecological economic geographies (see the Polish European Spatial Research and Policy). Others have focused on the complexities of regional innovation and uneven development (see the Slovak Region Direct). The RegPol ${ }^{2}$ group has taken uneven development, peripheralisation and regional inequality as its primary focus of training, research and publication. It is to this their latest book in this project that we have been invited to contribute a conversation (see also Lang et al. 2015 
and the special issue of the Hungarian Geographical Bulletin Vol. 64 (3) 2015 on "Discussing inequalities from the periphery").

I think it is interesting to note that we each came of age intellectually and politically in parallel contexts to those in the 1960s and 1970s, you in the Northeast of England and me in the Northwest. Each of our home regions was a key centre of nineteenth and early twentieth century industrialisation (the Northeast in coal, steel and shipbuilding, the Northwest in coal and textiles). Each benefitted from post-war regional economic rebuilding underwritten by Keynesian policies and state investments, the expansion of state-owned transport systems, and rapidly improved living standards and expanded forms of social consumption (particularly in health and education). The resulting consolidation of working-class power was - in the 1960s — inflected with new workers recruited from the Caribbean and South Asia and the resulting mobilisation of racialised notions of identity, rights, and entitlements, with different effects on the Northeast and Northwest. With Enoch Powell's articulation of the race card and what it meant to be "British" or "English" there began a long-term organic crisis of the working class, which was rapidly further fractured with Thatcherism and its mobilisation of head-on attacks on trade unions (especially the power of the National Union of Mineworkers) and working-class unity. These conditions and the shifting balance of social forces, in turn, led to a war of manoeuvre on the part of conservatism and business alliances. Mobilising the logics of crisis, Thatcherism launched a head-on attack, first on the National Union of Mineworkers and later on organised labour movements generally. Stuart Hall has called this period "the long march of the Neo-liberal Revolution" (Hall 2011, 1-2) where "open, competitive and unregulated markets, liberated from state intervention and the actions of social collectivities... is the response of a revived capitalism to the crisis of Keynesian welfarism" in the 1970s (Theodore et al. 2011, 15) fused with the evasion of state intervention by "going global”.

Thatcher's rejection of the 'social' as a meaningful category for public policy was underpinned by the idea that the social welfare state's commitment to social and regional redistribution weakened the fabric of individuals and families (welfare cheats, lazy workers, parasitic 
unemployed...) and was the cause of an economic crisis whose solution was a turn to radical individualism and markets. The result was an assault on forms of socialised common-good and the creation of various rounds of sectoral and regional crisis. You felt this directly with the deepening regional crisis of coalmining, steel making and shipbuilding and the rise of unemployment as Thatcherism bit ever more deeply, a crisis that drew university researchers into the domain of public action and economic geographers into the orbit of Marxian analyses of capitalism. For me the parallel experience was of regional crises of coal and textiles in Lancashire, periodic rounds of firm collapse and labour force shedding, and later the deepening regional impacts of racial capitalism in apartheid South Africa and regional economic involution following the collapse of central planning and the imposition of largely unregulated privatisation programmes in Central and Eastern Europe. In each of these cases, we have both been concerned to investigate in various ways the geographies of capitalist transformations and the ways in which they were politically determined, often at institutional levels well beyond the capacity of local communities to control.

This issue has been an abiding concern of your own work and in your 1991 Area paper "The North in the 1980s: new times in the 'Great North' or just more of the same" you addressed it directly by questioning the political role of discourses about regional revival and new times, arguing that state management of the regional economy was not ended by Thatcherism and neoliberalism, but its form of state intervention was changed. The new economy with its emphasis on affluence and housing market growth was, instead, "characterised by a continuing marginalisation of the region relative to the main centres of growth and affluence, both within the European Community and globally" (Hudson 1991, 55). At the time, you saw this form of dependency and marginalisation as "a structural feature of a state-managed region rather than a cultural attribute of its people" (Beynon 2017, 123), and this seems a particularly important and salient corrective to bear in mind when thinking of the contemporary conjuncture in post-socialist Europe, and perhaps Europe more generally.

Perhaps we might usefully begin with these experiences, not to suggest that the processes and patterns of today in CEE were prefigured 
in the UK decades earlier, but to think how the theories and practices of economic geography were developed out of specific contexts and conjunctures in post-war Britain. In them, post-war opportunity and optimism for a new social democratic future quickly deflated as new policies, forms of state action and configurations of political power emerged. Perhaps in these experiences, and in the ways economic geography responded to them, there may be lessons for the ways in which post-socialist economic geographies are experiencing and responding to the intensely uneven experiences of optimism, involution, and illiberalism of the present conjuncture.

Perhaps we can begin with a brief overview of how you came to economic geography, what your initial influences were in choosing that path, and how you see it has changed over the decades of your involvement.

Ray: Surprising as it may seem now, when I first went to Bristol as a geography undergraduate in 1966, I was more interested in physical geography; from what I'd experienced at school, it seemed to offer a more rigorous approach. So much of the rest seemed to be essentially regional description, with very little emphasis on explanation. However, once exposed to the new emerging human geography and locational analysis, with its focus upon the explanation of spatial patterns my interests quickly shifted. Peter Haggett was a wonderful teacher and then of course there was David Harvey, who taught economic geography and a third-year course on philosophy and methodology, which essentially became Explanation in Geography. But even as a third-year undergraduate I was becoming critical of the ways in which economic and social processes were conceptualised within the locational analysis approach, grounded in highly unrealistic assumptions about what people knew and why they made the choices in the economy that they did, and conscious of the need to delve more deeply into the why people behaved as they did. This was the time when behavioural geography was briefly flourishing and my $\mathrm{PhD}$ at Bristol was firmly in this mould. But by the time I was finishing, I was already becoming critical of the way in which the focus on individual decisions in its turn also provided a very under-socialised account of the economy and its geographies. 
So when I moved to a lectureship in Durham in 1972-and became conscious of the dramatic changes that had affected the economy of Northeast England, and the reasons for this-I began to be interested in more political-economic approaches, initially via underdevelopment theories but increasingly via Marxian political economy and the structural and institutional constraints and inequalities in class power that meant that while people made economic geographies, they did so in circumstances that were not of their own choosing. This set me on a path that I followed, with the odd diversion into some interesting culde-sacs, for the last 45 or so years.

John: In 1989, you began Divided Britain with the comment that Prince Charles had pointed to the danger of Britain becoming a divided realm. In the book you and Allan Williams argued that Thatcherism was creating ever deeper divisions among regions and social classes, an almost apartheid-like spatial ordering of the neoliberal space economy with rapidly emerging complex arrangements of new economic spaces and class forces competing with pockets of un- and under-employment across the region. This seems like an ideal opening for our discussion and its relation to this book's focus on regional uneven development and peripheralisation. How did you see this issue of division in Divided Britain?

Ray: From my point of view, Divided Britain was and remains a book very much shaped by the times in which it was written. It was published four years after the miners' strike came to an end, a strike for which the Tories had prepared meticulously when in opposition in the 1970s, had backed off conflict with the miners earlier in the 1980s, holding back until the situation was favourable and then deploying the power of the state to ensure that the miners were defeated. This was savagely demonstrated in the way in which police ran riot through the village of Easington Colliery in the summer of 1984 and most dramatically in the "battle of Orgreave". For once the miners had been defeated and the National Union of Mineworkers marginalised, then the attack on the post-war settlement, on the achievements of what, following Timothy Mitchell (2011), we might denote as a form of "carbon 
democracy", could be pursued with greater vigour as the boundaries of the state were selectively rolled back. One effect of this, coupled with the priority given to financial services and the City of London, was to inscribe regionally uneven development even more deeply into the landscape of capitalism in the United Kingdom as Thatcherism sought to sharpen and re-define socio-spatial divisions within the Divided Realm. It seemed to me important to document this and emphasise the way in which (re)producing socio-spatial division and uneven and combined development was not some unintended by-product but was a deliberate part of a political strategy.

John: Indeed, in the 1980s this notion of geographical uneven and combined development became a crucial concept for critical economic geography more generally. Adapted through various traditions of World Systems Theory, the development of underdevelopment, and dependency theory, Lenin's concept of combined and uneven development seemed to speak to many of us at the time. In particular, it provided a useful framework for breaking free of more traditional concepts of the region as bounded and unique by offering a richer, more political understanding of the relational nature of space and regional change. That the regional problem of, for example, industrial regions had so often been treated as a problem of the region itself, seemed theoretically banal and politically disingenuous. That the regional problem was always a problem of a wider series of spatial policies, processes, and practices was gradually becoming much clearer. Interestingly, in 1985 you published with Jim Lewis Uneven Development in Southern Europe. How did this focus on the economic geographies of southern Europe and the conference on which it was based ('National and Regional Development in the Mediterranean Basin') emerge?

Ray: As you rightly say John, by the 1980s the notion of uneven and combined development had come to occupy a central place in economic geography and some geographers were increasingly seeing regions as a product of both endogenous and exogenous processes; Doreen Massey had a significant influence here. I was also interested in seeing the changes that had occurred in the economy of the Northeast in a 
broader comparative context. Reflecting this, I began to spend time and carry out research in a range of other European regions-for example, regions that seemed to have a similar economic structure to the Northeast of England, such as the Ruhr in Germany, and Lorraine in France-and others that had had very different structures and developmental trajectories - for example, Jutland in Denmark and those regions of Northeast Italy which became known as the "Third Italy". In this context, southern Europe raised some interesting questions, not least because of the political transition from dictatorship to democracy in Greece, Portugal and Spain, and their subsequent entry into the European Community in 1981 and 1986. And other Mediterranean economies had also entered into a variety of trade and labour migration arrangements with Germany and France in particular. As a result, this raised questions for me about how these macro-scale changes in political economies related to changing patterns of uneven and combined development at national and sub-national scales. It was issues such as these that we hoped to explore through the conference and bring together in the book; the more limited focus on southern Europe was very much a reflection of the ways in which the three recent entrants to the European Community and Italy could be seen to share common characteristics but also important differences that reflected the uneven and combined character of development within the larger shared space of the European Community.

John: It is very interesting to me how these two works (one on combined and uneven development in Britain and the second a comparative analysis of uneven development in southern Europe) map out very useful methodologies for addressing the so-called 'regional problem' relationally and conjuncturally. In 1989, in the same year as Divided Britain you published another fascinating book: Wrecking a Region: State Policies, Party Politics, and Regional Change in North East England, in which you turned to the more detailed conditions of regional economic involution that were so deeply affecting the lives and livelihoods of people and places in the Northeast. How did Wrecking a Region with its rich local and contextual analysis come about and why did you 
choose in that book to focus on the role of state policies in shaping regional futures?

Ray: Good question! There is a real sense in which the book is autobiographical. I was born and brought up in Alnwick, a small market town in rural mid-Northumberland, just off the northern tip of the Great Northern Coalfield. My father worked as an electrician at Shilbottle Colliery, just south of the town. So, when I was growing up Alnwick was then located on a sort of cultural divide-mining areas to the south, agricultural ones to the north. Then in 1966 I went off to Bristol University, returning periodically in the university holidays to Alnwick. Over the six years that I was in Bristol, on these return visits I became increasingly conscious of coal mines closing, new factories opening; railway lines and stations closing while new roads opened; town centres ripped apart and then re-built in a very different style, often with new office blocks springing up alongside new shopping centres. There was all too visible evidence that the economy and built environments of the region were changing. All this raised questions about what was going on, and why; and talking to friends over the occasional pint seemed to confirm this sense that things were on the move, though not necessarily for the better. Then in 1972 as a result of a quirk of the academic labour market—and a paucity of available jobs-I was lucky to be offered a job at Durham, back in the region (albeit on the wrong side of that critical cultural divide, the river Tyne, the "big river" that Jimmy Nail was later to celebrate in song). And living back in the region, I became more and more aware of the way in which the region was changing and curious as to why it was changing in these ways. This seemed something that was worth investigating further, a promising new line of research that could have some practical and political relevance in the region.

As I began to research these issues-I was fortunate as a very junior academic to obtain a couple of quite big research grants from the Social Science Research Council and the Centre for Environmental Studies - what quickly became clear was the significance of state policies for the region; in a phrase, it had become a state-managed region. Its industrial economy was dominated by the nationalised coal, steel and shipbuilding industries, while the expansion of the welfare state had 
resulted in education, health care and public administration being the main sources of service sector employment and central to a significant change in the gender composition of the labour force. Put another way, the region, its industries and people had very much become a product of the broader post-war settlement, of the "One Nation" strategy that had been shared by Conservative and Labour governments alike over the post-war period. And it was this of course that Thatcherism sought-and from its point of view, successfully - to destroy. As such, taking apart the nationalised industries and public services that were central to economy and society in the Northeast was in turn central to the Thatcherite project and the region was to be on the front line, disproportionately affected by the transition from a "One Nation" to "Two Nation" strategy (which, as we discussed above, I'd written about more generally with Allan Williams). Focusing on the effects of the changing forms of state policies, of the ways in which nationalisation led to rationalisation, capacity cuts and job losses on a massive scale, and then the privatisation of what was left of those industries that had been at the heart of the regional economy therefore seemed to be important, both intellectually and politically.

John: Interestingly, Wrecking a Region appeared in the Pion Series 'Studies in Society and Spaces' edited by Allen Scott and Michael Storper. The first volume in the series was Mick Dunford's Capital, the State, and Regional Development, Wrecking a Region was the second volume, and Allen Scott's New Industrial Spaces was the third. In various and different ways, each of you were drawing on Marx's critique of political economy to expand the horizons of economic geography. How did you come to enter this scholarly space of economic geography and Marxian analysis? And, perhaps also, what was the specific conjuncture to which your work was responding at that time? What were the particular influences that shaped your thinking?

Ray: As I've sketched out earlier, from the early 1970s I began to get interested in Marxian political economy as a framework in which to begin to understand the uneven geographies of capitalist economies. There were a couple of loose organisational groupings that were important for me in developing my understanding of these issues. The first 
was the Regionalism Group of the Conference of Socialist Economists in the United Kingdom. Participation in this group, which included colleagues from a range of disciplinary backgrounds, became an important source of inspiration and support. Members of the group included James Anderson, Doreen Massey, Mick Dunford, Di Perrons, Gareth Rees, Mike Cuthbert, Andrew Sayer, Nick Rogers, and Martin Boddy. It met fairly regularly and provided a forum in which left-leaning academics could discuss their work and more generally the ways in which the "regional problem" was both changing and being understood in new ways. In addition to, and in parallel with, this, I found engagement with a number of people in Europe-Alain Lipietz, Pieter van Hoogstraten, Viggo Plum, Henrik Toft Jensen and Costis Hadjimichalis, for example-very helpful, as was the influence at a distance of David Harvey. This European context opened up literatures of which I'd previously had little knowledge-for example, German state theory, and Italian social scientists studying uneven development in Italy-and perspectives that were both cross-national and cross-disciplinary. In the 1980s the establishment of the "Seminars of the Aegean" provided an important ongoing forum in which these issues could be discussed further. The seminar met every two or three years on various Greek Aegean islands and provided a very positive, constructively critical cross-disciplinary and cross-national cultural setting that brought together a range of leftist academics, predominantly drawn from Europe and with occasional visitors from across the Atlantic such as Ed Soja and Dick Walker. Regular participants included Costis Hadjimichalis, Dina Vaiou (who, with other Greek colleagues both committed a great deal of their time to the organisation of the seminars), Lila Leontidou, Lois Labrianidis, Maria Dolors Garcia Ramon, Vicente Granados, Giacchino Garofoli, Enzo Mingione, Enrico Pugliese, Alain Lipietz, Henrik Toft Jensen, Viggo Plum, Mike Edwards, Mick Dunford, Jim Lewis, Di Perrons and Andrew Sayer. Some of us also became involved in European Community ERASMUS networks.

John: Given the importance currently placed in European universities and funding agencies on research networks, these earlier collaborations and exchanges are important to know about. The period certainly was an exciting one as the European Left struggled with the growing 
consolidation of neoliberalism and its attacks on organised labour and the wider gains of socialism and social democracy. You take this on directly in your writing, which is clearly grounded in a deep commitment to what might now be called variously 'activist' or 'engaged' scholarship and grounded research methodologies, particularly around the miners' strikes and the struggle with Thatcherism.

Ray: Yes, the miners' strike of 1984/1985 had a very important longerterm consequence for my work. Because a growing shared interest in the future of deep coal mining in County Durham, and the threat posed to this by the Thatcher government, led me to begin to work with Huw Beynon, a collaboration that has now continued over almost four decades and given rise to a number of joint publications (for example, see Beynon et al. 1991). In the years leading up to the strike, Huw had been both researching and working with the Durham Miners Association and he became actively involved in the strike itself. In parallel I was working with Easington District Council to demonstrate the implications of closing collieries and the loss of jobs from mining on the labour market in Easington. This covered the costs of job loss in terms of increased public expenditure on welfare, but also the less tangible costs to individuals and to communities in terms of family break-up, social dislocation, growing problems of mental health and so on. We produced a major report, Undermining Easington, which became the focus of a televised party-political broadcast by the Labour Party. Along with other research, this led to my involvement as a Special Advisor to the House of Commons Select Committee on Coalfield Regeneration and as Special Advisor to a National Audit Office evaluation of the regeneration programmes. There's one more thing worth adding at this point. In the early 1980s Huw and I had both come to the conclusion that there was a clear link between the expansion of private sector opencast mining in Durham and the closure of the nationalised deep mines and this led to a further major research project on the expansion of opencast and its effects (see Beynon et al. 2000). And we continued to document the longer-term effects of the closure of the mines and this will be the focus for our next book (Beynon and Hudson 2019). In all of this we have worked closely with a succession of research students 
and researchers, involving the residents of the former coal districts and the miners' unions, and involving both local residents and former miners as researchers.

John: As we have seen, in your research and writing from the 1980s and 1990s you were closely involved in analysing the complex relationships between local and national struggles over public policy and regional development. By the early 2000s your work seems to have changed its tone and focus a little. Here 'place' seems to have become more central, at least in framing the titles of your writing. For example, in 2000 you published Production, Places, and Environment: Changing Perspectives in Economic Geography and in 2001 your Producing Places was released. Did this use of 'place' as a central concept reflect important shifts in your thinking and engagement with economic geography at the time? I wonder how you see the relationship of place as a political object, as well as an object of theory and analysis, to your earlier concerns with the future of regions?

Ray: There is a sort of connection between those two books, as the first was essentially a collection of previously published work while the second was an attempt to provide a new and more thorough statement of the way I was seeking to understand economic geographies. And as I made clear in the Preface to Producing Places, it can also be seen as developing ideas that were rather briefly stated in the Preface to Wrecking a Region. There was a deliberate sense of ambiguity in the title of Producing Places, focused on the meaning of "place". On the one hand, it referred to those places in which the activities that constitute the economy are performed (factories, offices, shops, homes and so on) and the ways in which these places fit into technical, social and spatial divisions of labour, within and across both private sector companies and public sector organisations. Secondly, however, it refers to the production of "places" as located at the intersection of realms of use values and exchange values. In these places capital—supported directly and indirectly in a variety of ways by the state - seeks to produce profits via the exploitation of labour but these are also places defined by the fact that people live there beyond their existence merely as the providers of the 
commodity labour power. They are socialised human beings, with a variety of attachments and ties to their place, to other people and other places. As a result, places are porous, constituted via the interplay of endogenous and exogenous processes, and are always reproduced in precarious conditions, as the requirements of capital and states on the one hand and people in their place on the other can become dislocated and come into conflict. This became very clear in the strikes in the French steel industry in the early 1980s and in 1984/1985 in the miners' strike in the United Kingdom, for example. Put another way, the institutions and mechanisms through which places are reproduced as such are a matter of some political importance. However, as Raymond Williams made clear, moving from place-specific "militant particularisms" to more broadly-based political movements can be problematic and one consequence of this is that "places" can be drawn into conflict and competition for investment and jobs, often as a result of local or regional alliances between the institutions of capital and labour, dividing the working class on the basis of place.

There's one more thing I'd mention about Producing Places, however, which is an explicit recognition that economic activities always involve material transformations, relations between the social and natural as well as the social and spatial. Given the empirical focus of a lot of my research-on the coal, chemical and steel industries for example, industries in which the chemical and physical properties of material and products was critical in the production of use values, and hence exchange values - this was something I felt had been rather neglected to that point in my own work and by most economic geographers more generally. To put it simply, coal is far from being a homogeneous substance, with a variety of chemical and physical properties that constrain its uses, while the steel produced for car bodies is very different to that produced for the working parts of engines. And these differences matter. Although what I had to say about these issues there was limited, it did point to one direction in which my work would extend more deeply in future-and also suggested that economic geographers interested in these issues would need to engage seriously with work in the natural sciences to understand processes of material transformation. 
John: Following along this line of thinking about the changing concepts and forms of inquiry in economic geography, I was intrigued and excited by your 2005 Economic Geographies: Circuits, Flows and Spaces. My own work in socio-spatial theory, political economy of development, cultural studies, and post-socialism has been heavily influenced by Althusserian Marxism, Foucauldian genealogy, the diverse and alternative economics projects of JK Gibson-Graham, David Ruccio, and others, and the development of Gramscian conjunctural analysis in the cultural studies of Stuart Hall, Doreen Massey, Larry Grossberg, and John Clarke among others. From these perspectives, the analysis and diagnosis of the regional problem of inequality and peripheralisation requires a complex articulation of forms of over-determination, relationality and context that is both economic, cultural, and political. This was the project of my book with Adrian Smith and colleagues (Articulations of Capital and earlier with Theorizing Transition and Environmental Transitions). Your Economic Geographies is fascinating in this sense because of its open view of the field. It is organised around a series of shifts in emphasis occurring at the time from economic geographies of production to the ways in which geographers were focusing on patterns of consumption, nature, and culture in economic life. Here explanation grounded in socio-spatial relations of production are reworked into a fascinating and pedagogically useful framing of the thoroughly complex, contingent, and over-determined nature of economic life. These currents opened up some sharp engagements among various readings of economy, class, and identity among political economists. Yet you seem to have always risen above those fractures and often sharp engagements. At the time, how did you navigate these wider currents changing the kinds of questions about the region, place, and politics that had so infused your earlier work?

Ray: Well to some extent Economic Geographies can be read as seeking to fill in some of the gaps in Producing Places, and in so doing to engage with new and emergent strands of economic geography. Even before the publication of Producing Places, I had become increasingly aware of three related areas of development in economic geography and, in some respects, in the social sciences more generally. First, there was an 
increasing interest in consumption (or perhaps more accurately in many cases, the moment of sale and the realisation of surplus value embodied in commodities), complementing the emphasis in much earlier work on production and the labour process at the point of production. Secondly, something I'd recognised and begun to register, albeit inadequately, in Producing Places, a growing interest in the grounding of the economy in nature and the centrality of relations between ecology and economy (or perhaps better, economies). And thirdly, a growing interest in cultural approaches to understanding economic geographies, which were seen as offering alternative "bottom up" approaches to the variety of "top down" political economy perspectives that for the previous two or three decades had been dominant (and on which I had drawn heavily in Producing Places). These developments raised some intriguing questions for me.

In part, this was because in various ways they took me back to much earlier work. My PhD thesis, for example, produced in the dim and distant past environment of behavioural geography, was very much concerned with how consumers made choices about which shops and shopping centres to patronise, and how they learned about the retailing environment. Much of my subsequent research had in one way or another focused on the geographies of the coal, chemicals and steel industries, each of which in its own way raised important questions about the materiality of production and the relationships between economy and environment, as I indicated above. But more fundamentally, these developments revived important theoretical questions about understanding the totality of the production process in capitalism, the links between processes of production, exchange and consumption and their relationship in socio-spatial divisions of labour and their significance for the process of capital accumulation.

What I was seeking to do in Economic Geographies was to develop a more nuanced approach, drawing upon a range of theoretical perspectives, that allowed economic geographies to be explored in a number of registers and draw upon political economy and cultural perspectives as complementary, while holding on to the established strengths of political economy perspectives. In many ways it can be seen as an attempt to return to the traditions of political economy prior to the neo-classical 
marginalist revolution, which reduced economics to an arid technical exercise in mathematical modelling of the patently unrealistic, and to reconnect analyses of production, exchange and consumption, sensitive both to the cultural construction of economies - the constitutive activities of which are always meaningful and intentional, although with effects that are not always those intended-and the material grounding of the economy in the natural world.

John: I find the centrality of this concept of the cultural construction of economies to be a productive one, in part because it means that we can no longer 'simply' read off the politics of a group from its economic or class position. This was the great challenge facing political economy grounded as it was in earlier assumptions of productivism and very particular conceptions of class. Engaging with the multiple ways in which people construct their relationship to economic and political issues is one of the abiding strengths of critical geography, although its success remains a question for many. I think the concepts of cultural construction, intended and unintended consequences, and materiality help a great deal in opening up what contemporary economic geography might mean.

A crucial form of such grounded materiality is, of course, embodiment. The struggle of the miners was often, and perhaps always about the integral relations of the body of coal and the body of the miner; one torn out of the earth to create use value, the other wracked to create surplus value. These two forms in turn contributed to a wider embodiment and gendering of the family. In my own home region, the mould of mining family structures was, to some extent, reworked as women found employment in textile factories. Linda McDowell and Doreen Massey have written wonderfully about the consequences of this gendering of work and space and for the differential politics of Thatcherism among working-class men and women and feminist geographers, in particular, have opened up questions of how agency and power are understood in economic geography (McDowell and Massey 1984; McDowell 2004).

Another fundamental shift that was taking place in the Northeast and Northwest was, of course, expanded immigration. From the 
$1960 \mathrm{~s} / 1970 \mathrm{~s}$ on increased numbers of immigrants arrived in the Northeast from the Caribbean and in the Northwest from South Asia. My initial teenage experiences of the resulting regional and cultural politics were focused mostly on the pleasures of popular culture, the music of Motown and Northern Soul, struggles of the American Civil Rights Movement, national media and political closure around the claims of anti-colonial liberation movements and the population of radicalism following the worldwide events of 1968. The lasting effects of these and subsequent cycles of immigration have, however, been very different from those we hoped for as white working-class attitudes have hardened and social and urban lives have become deeply segregated. I left Britain in the 1970s but I have returned regularly and often. Over this time, and while some parts of British life have become more diversified and cosmopolitan, in the Northwest the racialisation of space and divisions between communities have deepened. White working-class attitudes towards internationalism and solidarity, once strong in a region where the Suffragette Movement and Independent Labour Party took root early, seem to have given way to Little Englandism, xenophobia, and deep social rifts.

Ray: Coming from a mining background, I'd always been conscious of the relationship between the embodied work of male miners underground-work that was dangerous and that all too often led to fatal accidents — and the domestic labour of their wives and daughters in the home that was crucial to the reproduction of the mining labour force. In families in which both fathers and sons worked on different shifts in the collieries women could be involved in a constant round of providing hot meals and hot water around the clock because of the nature of shift working underground. The unpaid domestic labour of women was crucial in sustaining this. Family life and the social fabric of the mining communities became structured around the sound of the hooter signalling the start and end of shifts. But at the same time the critical social institutions - the trade union, the Labour Party and the working men's clubs - were dominated by men. Quite a few clubs wouldn't let women through the door, and in those that did they were confined to a particular room. So there were tensions, and it is important to recognise 
this. But as became clear in 1984/1985, a year in which many women became heavily involved in supporting the strike, they were prepared to fight in defence of their place. One of the consequences of the events of that momentous year is that a number of women became politically active in the former mining communities, as well as many more becoming the main wage earner in families in which redundant miners became part of the long-term unemployed. In these ways, gender relations both in the home and community became changed in important ways across the former coalfield communities.

I think the issue of ethnicity and race worked out rather differently in the Northeast as compared to the Northwest. There were certainly immigrant communities in parts of Tyneside and Teesside, long-established and linked to the maritime history of the riverside conurbations, but more generally the region was relatively unaffected by the waves of immigration from the Commonwealth. There were certainly some wellknown West Indian cricketers who were recruited by local league teamsRohan Kanhai for example at Ashington (incidentally, once the world's largest coal mining settlement, and the place where my father's family came from) - but by and large the region remained one dominated by the white English. This, coupled with an industrial past that was often linked to producing the means of destruction that were central to the politics of the Empire - guns and warships and so on-did have an effect on the nature of politics, on the character of the Labour Party and its domination by a socially conservative Labourism, and in places on the development of a regressive nationalism-one expression of which was the vote to leave the European Union in the referendum in 2016, in places with little experience of immigration but in which people nonetheless expressed fears of waves of non-existent immigrants taking their jobs ....

But one of the implications that I drew from all this in terms of how we should think about economic geography is that it needed to take on board these ethnic and gender differences and effects in the way that it understood the formation of identities and their relation to more structural understandings of class position as well as the economic and social restructuring of regions like the Northeast and divisions within the working class more generally. I began to explore some of this in Producing Places in a preliminary way. 
John: You revisited these themes in your 2005 Antipode Lecture to the RGS/IBG where you frame the notion of a "pluri-theoretical" geography while arguing for the continued importance of Marxian approaches. Critical economic geography in Central and Eastern Europe has several challenges in taking on-board such a critical pluri-theoretical approach. First, it has had a very different experience of Marxism through Marxism-Leninism of a very particularly state socialist or state capitalist form. Here, neoliberalism was initially, and perhaps today still is, embraced for the political power of liberalism in confronting authoritarian politics, whether of a state socialist form or an unregulated, mafia-oligarchic capitalist form. Second, in the early years following 1989 regional science and locational analysis emerged as particularly important forms of economic geography because of their perceived 'clear' value for state planning agencies in transitioning centrally planned and collective infrastructures to emerging market-based private property regimes. In your various engagements with post-socialist scholars, how have you come to deal with the ways critical thought is situated and inflected differently? Or perhaps more concretely, how do you see Marxian approaches contributing to the analysis of uneven development and peripheralisation with the space economies of post-socialist Europe? What is Right about keeping Left in this context?

Ray: This is a tricky one, especially in conversations with those who were subjected to, as you nicely put it, "Marxism-Leninism of a particularly state socialist or state capitalist form". So, at the risk of repeating myself, I would continue to argue that Marxian political economy is fundamental to understanding uneven and combined development in capitalism. As with other regions in (so-called) "emerging economies", this is the case for those parts of Central and Eastern Europe that are being incorporated into the dominant circuits of capital, a process which is transforming their economic landscapes, inscribing new forms of uneven and combined development, and in some ways reinforcing existing ones. Marxian political economy is the only perspective that seeks to develop a holistic conception of the way in which capitalist economies are constituted and change, structured around the capital-labour class relation, and that allows a rigorous specification of 
the structural parameters of capitalist social relations. That said, let me make a couple of qualifications. First, capitalism now is very different to the capitalism that Marx was dealing with in the middle of the nineteenth century, and indeed from the capitalist world that Lenin and Luxemburg analysed in the early decades of the twentieth century. And as we've discussed above, in the latter decades of the last century, there was a significant shift in the advanced capitalist world from social democratic to neoliberal forms of regulation and capitalist (dis)organisation. As a corollary of such transformations in the character of capitalism, it is necessary to develop modes of analysis that are sensitive to and can deal with such variation, with what have become referred to as "variegated capitalisms", while recognising that these continue to be forms of economy grounded in the fundamental class relations of capital. So, reflecting this, I do not see Marxian political economy as a fixed dogma but rather as an evolving, analytically powerful, conceptual framework that allows the changing character of capital accumulation and capitalist economic geographies to be grasped and understood. Put another way, it is to see Marxian political economy as something that needs to be worked upon and worked with-as David Harvey has brilliantly demonstrated. That said, I would also argue that other perspectives, such as those of feminism, and other political economy perspectivesevolutionary and institutional economics, for example - can complement Marxian approaches, since they focus on aspects of how capitalist economies develop and function, but it is only Marxian political economy that has the question of why they develop as they do at its heart. I've explored some of this further in a more recent book, Approaches to Economic Geography: Towards a Geographical Political Economy (2016).

John: The value of linking Marxian analysis to pluri-theoretical traditions and diverse concepts of space and economy is also the theme of your engagement with networks, regional development and democratic control with Costis Hadjimichalis (Hadjimichalis and Hudson 2006). I think our readers might first be interested in learning a little more about your collaboration with Costis and the kinds of linkages there are between your work and his on regional development and political economy. Second, I want to ask about how this concept of regionally 
embedded networks and urban and regional policy networks might operate as a useful analytical tool for thinking about the contemporary conjuncture in post-socialist societies. We have already talked a little about relational concepts of space. Here relationality is mobilised through a slightly different term or metaphor and perhaps to a distinctly political intervention in policy development, particularly as such networks "deny their constitutive inequalities, asymmetries and democratic deficits" (Hadjimichalis and Hudson 2006, 858).

Ray: Well I've known Costis for well over thirty years and we've worked together at various times over those years. There are a couple of things that I think are particularly significant about his work. First of all, he has always had a political view of Marxian political economy. Secondly, a concern with differing forms of uneven development has always been central to his work. And thirdly, he has a deep grasp of the specificities of uneven development in the context of southern Europe. Thus, in many ways, although the empirical foci of our research have been quite different, conceptually we share common ground, which opened up opportunities to collaborate and bring together work on the connections between uneven development in the 'north' and 'south' of Europe. As the quotation above makes clear, we share a healthy scepticism about the claims being made for networked approaches to regional development in the peripheries of Europe, in particular the way in which-along with much of the rest of the 'new economic geography'-they erase a concern with inequalities in power which we would see as central to capitalist economies. So in response to your specific question about how such concepts of urban and regional policy networks might be used for thinking about the contemporary conjuncture in post-socialist societies, my response would be: "if you use them at all, do so very carefully and cautiously. But in fact, you'd be better off not using them at all, because of the risks of amplifying rather than narrowing socio-spatial inequalities in pursuit of allegedly but in practice unattainable win-win outcomes".

John: Thinking of Costis and networks reminds me that you and he were involved in one of the first Erasmus networks in 1983, initially 
with Durham, Roskilde and Thessaloniki (Hadjimichalis 2017, 126). We have both long held strong views on the importance of collaboration with colleagues across the region and have made many commitments to building collaborative networks and publishing with them. In the face of increasing pressure on younger scholars to publish in Tier 1, often English-language journals, and to focus more and more on single authorship, this commitment to collaboration and co-authorship is ever more difficult in post-socialist academies. I wonder in what ways you might see the Erasmus experience and the subsequent collaborations with colleagues across Europe to have methodological lessons for the practice of contemporary critical economic geography?

Ray: I've already alluded to the importance of the links I developed with colleagues in Europe in the 1970s and 1980s, and the ERASMUS networks in which quite a few of us became involved-I think by the mid-1990s there were around 25 of us involved in the biggest of these-were very important in extending our collaborative work beyond research into education and teaching. As well as allowing students to study in different European countries, to experience often radically different styles of learning and teaching, it also allowed staff-especially those at or near the start of their careers - to get experience of life in universities in other countries and to form collaborative links with colleagues there-which of course often developed to include joint research. I think this was quite important in creating the sort of network that is valuable to those of us interested in developing understanding of the varied geographies of capitalisms. I think it is also fair to add that while these were schemes funded by the European Community, and many of us shared a commitment to Europe (ask me my nationality and the answers, in order, are Northumbrian, European, English ...), this was not the neoliberal post-Maastricht European Union but rather a transformed European Union, one committed to, at a minimum, a social democratic project. It is a matter of some regret that this looks off the agenda for the foreseeable future.

John: The ERASMUS program sought to create new forms of scholarly internationalism as part of the project of building a transnational 
Europe and it began shortly after you published Regions in Crisis. New Perspectives in European Regional Theory. The European project today looks a great deal different than it did in 1980 and 1983, although the analytical focus on crisis may still be a useful one. Recently, you have questioned the project of the EU because it has remained an elitist and top-down project where widening and deepening processes failed to build popular consent. As a result, not only is the EU now seen by some as coercive, competing with national interests, but it has been "a project of and for the political and capitalist economic elites of Europe, creating a new space for capital accumulation and a new political territory that would allow those who rule to have an equal voice with the USA and USSR on the world stage. Put another way, the emergent EU was an expression of a certain class conception of Europe and Europe's place in the world" (Hudson 2017, 139). Here your criticism of the class project of this particular form of 'Europe' perhaps refracts in interesting ways with other possibilities of thinking 'Europe', such as the internationalism of the early ERASMUS networks. Given the apparent deadlock of political forces around the Brexit referendum and the deepening of national antagonisms towards the EU project in other member states, do you see any alternative paths for the reconstitutions of an "other Heading" (as Derrida (1992) suggested) or an 'After Europe' (as the Bulgarian Ivan Krastev [2017] has argued).

Ray: Well, the short answer is that I'm afraid I see no scope for optimism here. There was a time when it did seem that there was scope for some optimism but the way in which the European Union has developed post-Maastricht has put an end to that. The creation of the euro and Euroland, with the fraudulent construction of statistics to enable economies such as Greece disastrously to join, dominated by a monetary policy that is de facto that of the Bundesbank, deeply engrained in an ordoliberal view of the policy world, is guaranteed to reproduce heightened forms of uneven and combined development in the shared European space, especially between the national economies and states of 'north' and 'south' and 'east'. The European Union is trapped between the aspirations of political and economic elites for further political integration driven from the top down and growing resistance, much of it 
framed within regressive right-wing nationalisms and regionalisms that seek to assert older political rights. As such, it staggers from crisis to crisis, with the Brexit episode providing a focus around which the remaining member states can for the moment agree. But once the UK leaves-assuming it does-then the tensions among member states around other issues will re-surface with a vengeance. In the absence of a democratic mandate from the citizens of Europe, further attempts at political integration seem doomed to failure-and so does any realistic prospect of a more socially and economically progressive vision of Europe.

John: In the light of the Brexit referendum, Scottish independence possibilities, and the deepening of the North-South divide with the continued growth and dominance of London and the Southeast, I wonder how you might conceptualise Divided Britain, Wrecking a Region, or Producing Places were you to write them today?

Ray: Interesting question! Huw Beynon and I are just finishing a book that argues that the Brexit vote in the coalfields of Durham and South Wales represented the end-point of a long historical process. To put it very briefly, while nationalisation in 1947 seemed to be a great victory for the coal miners and the coalfield communities, the subsequent reality proved very different. By the 1960s hundreds of collieries were closing and miners were losing their jobs in large numbers. But there did seem to be a political commitment from the Labour government to attract alternative jobs to the coalfields. After a brief period in the 1970s when it seemed coal again had a bright future, the election of the Thatcher government in 1979 made it very clear that this was not the case. While the redundant miners and those living on the former coalfields had little expectation of help from the Tories, they did so from Labour, not least because of the historical links between the Labour Party and the mining unions. Consequently, when it then became clear that Blair's New Labour had simply adopted the economic policies of the Thatcherite Tories, a deep disillusionment both with New Labour and with party politics irrespective of party developed on the former coalfields. The experiences of austerity under various governments after 
the global crisis of 2007/2008 simply reinforced this view. People felt powerless, their needs ignored, disillusioned with the politics of representative democracy as falling participation in elections revealed. As a result, when the opportunity to stick two fingers up to the political system came for the first - and only-time with the Brexit referendum, the view of many was "well, if the politicians think it's a good thing, then let's vote against it". The argument from the Chancellor of the Exchequer, George Osborne, that leaving the European Union would put what you had at risk cut absolutely no ice with people who saw themselves as having lost all they had many years ago. Given all this, any analysis of uneven and combined development in the United Kingdom today would have to start from a recognition of deeply engrained socio-spatial divisions at multiple spatial scales, of decades of economic and spatial policies that have reinforced this, of a context in which there is deep distrust of politicians of all parties, and with the United Kingdom's position in the global as well as European economy in doubt. While the decline of financial services in the City of London might reduce some socio-spatial inequalities, it would be in the context of a weakened national economy as for all the talk of re-balancing the economy, sectorally and spatially, there has been scant evidence of any revival of manufacturing or of the narrowing of socio-spatial divisions. Indeed, Brexit would be likely to see further deindustrialisation as capital re-locates in response. However, in terms of seeking to understand how and why this has come about, a starting point in Marxian political economy would be at least as important as when I first wrote those books.

John: This last series of exchanges leads me to think about engaged scholarship and the relationships between research, policy, and politics. Perhaps more than most economic geographers, you have taken your scholarly work into regional and national organisations, as well as into university administration. I think of Doreen Massey who exemplifies the former and perhaps Nigel Thrift the latter. You have done both and I wonder what this means for how you have come to understand the value, and perhaps limitations, of contemporary economic geography in dealing with regional inequalities and possible new futures. 
Ray: I think it'll be clear by now that in the present conjuncture I'm not optimistic about the possibilities for narrowing regional inequalities in the UK. There has been quite a lot of talk at various times about spinning out intellectual property from university scientific research as the basis for innovative new high-tech firms that would form the basis of revived regional economies in regions such as Northeast England and South Wales. But while there have been occasional 'success stories'which have been richly rewarding for those academics whose research results have become commodified in this way-overall such developments have had, at best, a marginal effect, a thin veneer drawn over and barely scratching the surface of otherwise depressed economies. Of course, whether it was ever sensible to suggest anything other than such an outcome is another question, but many universities seized on the possibility as a way of seeking to justify their existence while regional development organisations were only too happy to cling to this particular straw. That is not to say that university research could not have a positive role in ameliorating the consequences of uneven development and informing alternative development strategies, but this was more likely to be research in the social rather than the natural and engineering sciences and to focus on coping with and adapting to new economic circumstances. Certainly, there could be a role for some sort of economic geography in this, but not those that claim to see the world as one in which a few changes in individuals' attitudes and institutional change at the local and regional level would suffice to guarantee economic regeneration. In some ways the lessons from Marxian analyses of uneven and combined development are painful ones for they make clear that for many places and the people living in them there are no quick and easy solutions-or even slow and painful ones. The reality of capitalist economic development is that it is genetically uneven and combined but what we can learn from the economic geographies of "variegated capitalisms" is that some forms of capitalism are more progressive than others, that some forms of capitalism are preferable to others, and that we should seek to encourage and support these. And my final comment would be this: there is great danger in raising hopes that cannot be delivered, not least as this runs the risk of undermining the democratic process and without the active engagement of people 
in political projects that seek to find new ways of organising economic activities, then economic development will continue to be marked by deep socio-spatial inequalities. Economic geographers-among others-need to engage in the intellectual project of understanding existing forms of uneven development and imagining forms of development that would provide an alternative to these. Economic geography needs to be explicitly a political economic geography.

John: I am sure that this understanding of thinking politically and geographically about the structures of variegated capitalisms resonates clearly not only with British scholars struggling with the United Kingdom's internal and external regional relations, but also with our colleagues throughout Central and Eastern Europe whose own economic geographies have had to adjust to rapidly changing political economies in recent years. They have experienced rounds of intense optimism and pessimism about the efficacy and effects of wildly different forms of regional policy and the consequences each has had for economic development. Ray, it has been a pleasure to discuss these matters and I hope our time here contributes usefully to those ongoing conversations.

\section{References}

Beynon, Huw. 2017. "People, Place and Politics: The Anatomy of Dispossession in the Geography of Ray Hudson." European Urban and Regional Studies 24 (2): 122-25. https://doi.org/10.1177/0969776416689225.

Beynon, Huw, and Ray Hudson. 2019. The Road to BREXIT ...

Deindustrialisation and the Destruction of the Coalfields (Forthcoming).

Beynon, Huw, Andrew Cox, and Ray Hudson. 2000. Digging Up Trouble:

The Environment, Protest and Opencast Coal Mining. London: Rivers Oram Press.

Beynon, Huw, Ray Hudson, and David Sadler. 1991. A Tale of Two Industries:

The Contraction of Coal and Steel in North East England. Milton Keynes: Open University Press.

Carney, John, Ray Hudson, and Jim Lewis, eds. 1980. Regions in Crisis. New Perspectives in European Regional Theory. London: Croom Helm. 
Derrida, Jacques. 1992. The Other Heading: Reflections on Today's Europe. Bloomington: Indiana University Press.

Dunford, Michael. 1988. Capital, the State and Regional Development. London: Pion.

European Spatial Research and Policy. An International Journal Concerned with the Problems of Social and Economic Space Organisation at Local, Regional and Supranational Level. University of Łódź and De Gruyter Open. https://www.degruyter.com/view/j/esrp.

Hadjimichalis, Costis. 2017. "Encounters with Ray Hudson: A Very Personal Note." European Urban and Regional Studies 24 (2): 126-28. https://doi. org/10.1177/0969776416689219.

Hadjimichalis, Costis, and Ray Hudson. 2006. "Networks, Regional Development and Democratic Control." International Journal of Urban and Regional Research 30 (4): 858-72. https://doi.org/10.1111/j.1468-2427.2006.00687.x.

Hall, Stuart. 2011. "The Neo-Liberal Revolution." Cultural Studies 25 (6): 705-28. https://doi.org/10.1080/09502386.2011.619886.

Harvey, David. 1969. Explanation in Geography. London: Edward Arnold. Hudson, Ray. 1989. Wrecking a Region: State Policies, Party Politics and Regional Change in North East England. London: Pion.

Hudson, Ray. 1991. The North in the 1980s: New Times in the 'Great North' or Just More of the Same? Area 23 (1): 47-56.

Hudson, Ray. 2000. Production, Places and Environment: Changing Perspectives in Economic Geography. Harlow: Prentice Hall.

Hudson, Ray. 2001. Producing Places. London: The Guilford Press.

Hudson, Ray. 2005. Economic Geographies: Circuits, Flows and Spaces. London: Sage.

Hudson, Ray. 2006. "On What's Right and Keeping Left: Or Why Geography Still Needs Marxian Political Economy.” Antipode 38 (2): 374-95. https:// doi.org/10.1111/j.1467-8330.2006.00584.x.

Hudson, Ray. 2016. Approaches to Economic Geography: Towards a Geographical Political Economy. London: Routledge.

Hudson, Ray. 2017. "Facing Forwards, Looking Backwards: Coming to Terms with Continuing Uneven Development in Europe." European Urban and Regional Studies 24 (2): 138-41. https://doi.org/10.1177/0969776416689230. Hudson, Ray, and Jim Lewis, eds. 1985. Uneven Development in Southern Europe: Studies of Accumulation, Class, Migration and the State. London: Methuen.

Hudson, Ray, and Allan M. Williams. 1989. Divided Britain. London: Belhaven Press. 
Krastev, Ivan. 2017. After Europe. Philadelphia: University of Pennsylvania Press.

Lang, Thilo, Sebastian Henn, Wladimir Sgibnev, and Kornelia Ehrlich, eds. 2015. Understanding Geographies of Polarization and Peripheralization. Perspectives from Central and Eastern Europe and Beyond. New Geographies of Europe. Basingstoke: Palgrave Macmillan.

McDowell, Linda. 2004. "Masculinity, Identity and Labour Market Change: Some Reflections on the Implications of Thinking Relationally About Difference and the Politics of Inclusion." Geografiska Annaler B 86 (1): 45-56. https://doi.org/10.1111/j.0435-3684.2004.00153.x.

McDowell, Linda, and Doreen Massey. 1984. "A Woman's Place?" In Geography Matters! A Reader, edited by Doreen Massey and John Allen, 124-47. Cambridge: Cambridge University Press in Association with the Open University.

Mitchell, Timothy. 2011. Carbon Democracy: Political Power in the Age of Oil. London: Verso Books.

Pavlínek, Petr, and John Pickles. 2000. Environmental Transitions: Transformation and Ecological Defense in Central and Eastern Europe. London: Routledge.

Pickles, John, and Adrian Smith, eds. 1998. Theorising Transition: The Political Economy of Post-Communist Transformations. London: Routledge.

Pickles, John, and Adrian Smith (with Robert Begg, Milan Bucek, Poli Roukova, and Rudolf Pástor). 2015. Articulations of Capital: Global Production Networks and Regional Transformations. London: Wiley-Blackwell. Region Direct. An International Journal Produced in Cooperation with the University of Economics Bratislava and the Faculty of National Economy, the Faculty of Economics Matej Bel University Banská Bystrica, Regional Science and Politics Association, and Regionálne európske informačné centrum Banská Bystrica. Regionálne európske informačné centrum Banská Bystrica. https://www.degruyter.com/view/j/regd.

Regional Statistics. Journal of the Hungarian Central Statistical Office, Budapest. https://www.ksh.hu/terstat_eng.

Scott, Allen J. 1988. New Industrial Spaces: Flexible Production Organization and Regional Development in North America and Western Europe. London: Pion.

Theodore, Nik, Jamie Peck, and Neil Brenner. 2011. "Neoliberal Urbanism: Cities and the Rule of Markets." In The New Blackwell Companion to the City, edited by Sophie Watson and Gary Bridge, 15-25. Chichester: Wiley-Blackwell. 
Open Access This chapter is licensed under the terms of the Creative Commons Attribution 4.0 International License (http://creativecommons. org/licenses/by/4.0/), which permits use, sharing, adaptation, distribution and reproduction in any medium or format, as long as you give appropriate credit to the original author(s) and the source, provide a link to the Creative Commons license and indicate if changes were made.

The images or other third party material in this chapter are included in the chapter's Creative Commons license, unless indicated otherwise in a credit line to the material. If material is not included in the chapter's Creative Commons license and your intended use is not permitted by statutory regulation or exceeds the permitted use, you will need to obtain permission directly from the copyright holder.

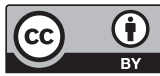

